\title{
PERSEPSI DAN PRASANGKA ANTARETNIK DI LAMPUNG SELATAN: STUDI KOMUNIKASI ANTARETNIK DI BAKAUHENI KALIANDA
}

\author{
Karomani \\ FKIP Universitas Lampung, \\ Email: aom_karomani@yahoo.co.id
}

\begin{abstract}
ABSTRAK. Daerah Bakauheni Lampung Selatan sebagai daerah pelabuhan merupakan daerah multietnik yang didiami beragam etnik Nusantara. Dalam masyarakat multikultur atau multietnik acapkali terjadi persepsi dan prasangka sosial yang buruk antaretnik yang disebabkan perbedaan latar belakang budaya. Penelitian ini bertujuan mendeskripsikan persepsi dan prasangka antar etnik Sunda, Jawa, Batak, Lampung dan Sulawesi (Bugis) di Bakauheni Kalianda Lampung Selatan. Metode penelitian yang digunakan dalam penelitian ini adalah metode kualitatif dengan alat pengumpul data wawancara mendalam. Hasil penelitian menunjukkan bahwa etnik Lampung, Bugis, Batak dan Sunda 100\% berpersepsi bahwa orang Jawa sebagai etnik yang "halus atau lembut "tutur sapa dan perilakunya. Sama halnya terhadap etnik Jawa, kecuali etnik Lampung hanya $90 \%$ dan etnik Jawa hanya $80 \%$, etnik Bugis dan Batakpun $100 \%$ berpersepsi bahwa etnik Sunda termasuk "halus" pembawaanya. Demikian pula, kecuali etnik Lampung hanya $70 \%$, etnik Batak, Jawa dan Sunda $100 \%$ berpersepsi bahwa orang Bugis adalah "pemberani". Kecuali etnik Lampung hanya $80 \%$, etnik Bugis, Jawa dan Sunda $100 \%$ berpersepsi bahwa orang Batak juga sebagai "pemberani. Kemudian terhadap etnik Lampung, kecuali etnik Jawa hanya $90 \%$, etnik Bugis, Sunda, dan Batak berpersepsi orang Lampung juga sebagai "pemberani". Etnik Lampung, dan Batak $60 \%$ berprasangka bahwa etnik Jawa "penakut". Sementara etnik Bugis $90 \%$ berprasangka bahwa etnik Jawa "feodal" dan etnik Sunda $60 \%$ berprasangka orang Jawa "sekuler". Etnik Lampung $60 \%$ berprasangka orang Sunda "penakut" dan "pemalas". Sementara etnik Bugis berprasangka orang Sunda "feodal". Etnik Batak $60 \%$ lebih berprasangka orang Sunda "penakut, "boros, "pemalas" dan "tertutup". Terhadap etnik Bugis $60 \%$ lebih etnik Lampung, Sunda, Jawa, dan Batak berprasangka orang Bugis"angkuh", "kasar", dan "boros" hidupnya. Kemudian terhadap etnik Batak, 60\% lebih etnik Lampung, Jawa, Sunda, dan Bugis berprasangka bahwa orang Batak "angkuh",dan "kasar" prilakunya. Adapun terhadap etnik Lampung $60 \%$ lebih etnik Sunda, Jawa, Bugis dan Batak berprasangka orang Lampung "angkuh", "kasar" dan "pemalas". Aspek pengalaman seperti kedekatan pergaulan, aspek sosial budaya seperti agama, tingkat pendidikan, dan pekerjaan serta status sosial seseorang adalah faktor yang mewarnai persepsi dan prasangka antaretnik Sunda, Jawa, Lampung, Bugis, dan Batak di Bakauheni Lampung Selatan.
\end{abstract}

Kata Kunci : Komunikasi, Persepsi, Prasangka, Antaretnik, 


\title{
PERCEPTION AND PREJUDICE INTER-ETHNIC AT SOUTH LAMPUNG: A STUDY OF COMMUNICATION INTER-ETHNIC AT BAKAUHENI, SOUTH LAMPUNG
}

\begin{abstract}
The region of Bakauheni, South Lampung, is a port territory where many ethnics from Indonesia archipelago live there. In this kind of multiethnics or multiculture society, sometime there are a lot of misscommunications and missperceptions happen. This missunderstanding is caused by the differences in the social and cultural backround. This research is done in order to describe the different perceptions and prejudices betwen ethnic in Bakauheni, such as Sunda, Java, Batak, Lampung and Sulawesi (Bugis). The research was conducted using qualitative methode and data were obtained by using depth interview. Research findings show indicated that Lampung, Bugis, Batak, and Sunda ethnic have $100 \%$ of perceptions that Javanesse people have soft and smooth intonation in their speaking and their way of behave. It is similiar with Java ethnic, except Lampung ethnic 90\%, Java $80 \%$, Bugis and Batak ethnic also consider $100 \%$ that Sunda ethnic has soft character. In contrary, Lampung ethnic 70\%, Batak, Java, and Sunda ethnic consider $100 \%$ of Bataknesse as "brave" people. Then toward Lampung ethinc, except Java ethnic $90 \%$, Bugis, Sunda, and Batak ethnic also consider them as "brave" people. Lampung and Batak ethnic $60 \%$ regard of Java ethnic as "fearful" people. While Bugis ethnic regard $90 \%$ of Java ethnic as "feudal" and Sunda ethinc 60\% regard that Javanesse people are "secular". Lampung ethnic $60 \%$ considers that Sundanesse people as "fearful" and "lazy" people. While Bugis ethnic consdiders Sundanesse people as "feudal" people. Batak ethinc $60 \%$ considers that Sundanesse people as "fearful", "wasful", "lazy" and "introvert" people. Toward Bugis ethinc, more than $60 \%$ of Lampung, Java, Sunda, and Batak ethnic regard that these people as "arrogant", "crude" and "wasful" people. And toward Lampung ethnic, more than $60 \%$ of Sunda, Java, Bugis, and Batak ethnic consider that Lampungnesse people as "arrogant", "crude" and "lazy" people. Aspect of experience, such as social intercourse, social cultuural aspect like religion, level of education, occupation and social status are the factors that make these perceptions become different betwen Sunda, Java, Lampung, Bugis, and Batak ethnic in Bakauheni territory of South Lampung.
\end{abstract}

Keywords: Communication, perception, prejudice, inter-ethnic.

\section{PENDAHULUAN}

Daerah Bakauheni Lampung Selatan sebagai daerah pelabuhan dihuni oleh beragam etnik Nusantara antara lain etnik Sunda, Jawa, Bugis, Lampung, dan Batak. Sebagaimana dikemukakan Kades Bakauheni (wawancara tgl 19 Agustus 2008) rinciannya kurang lebih yaitu suku Lampung 28 persen, suku Jawa 50 persen, Batak 5 persen, Sunda 10 persen dan Bugis 3 persen dan sisanya 4 persen suku lain di luar suku tersebut.

Desa Bakauheni memiliki jumlah penduduk sebanyak 10.076 jiwa yang terdiri atas 2116 kepala keluarga. Tingkat pendidikan warganya relatif rendah sebagian 
besar 65 persen hanya tamat SD, 26 persen tamat SLTP, kurang dari 9 persen tamat SLTA. Mata pencaharian penduduk 57 persen petani, 26 persen buruh tani, 6 persen buruh swasta, nelayan, pegawai negari, dan pedagang masing-masing 2 persen sisanya. Sisanya montir sopir dan lain-lain. Penduduk desa ini 85 persen beragana Islam, 10 persen Kristen 5 persen Hindu dan Budha (Buku Profil Desa, 2009 : 9-10).

Bakauheni sebuah desa yang berada di wilayah Kabupaten Lampung Selatan Provinsi Lampung. Desa ini tepat berada di lingkungan pelabuhan penyebrangan Bakauheni - Merak Banten. Bakauheni-untuk arus barang, jasa dan orang dari Sumatra -- merupakan pintu gerbang masuk Jawa, dan sebaliknya merupakan pintu masuk dari Jawa ke Sumatra. Wilayah Bakauheni yang tepat berada di wilayah Selat Sunda merupakan daerah yang strategis; merupakan urat nadi arus barang, jasa dan orang dari dan ke Jawa dan Sumatra. Jembatan Selat Sunda yang digagas dua provinsi Banten dan Lampung berada di wilayah ini. Di daerah ini juga berdiri menara Siger mahkota dalam adat perkawinan masyarakat Lampung yang telah dijadikan sebagai ikon Provinsi Lampung. Monumen ini sebagaimana dikemukakan Aryanti dkk (2008:107) merupakan pusat informasi Lampung yang di dalamnya tercakup beragam informasi tentang sepuluh kabupaten yang ada Provinsi Lampung. .

Dalam masyarakat multikultur atau multietnik seperti di Bakauheni acapkali terjadi persepsi dan prasangka sosial yang buruk antaretnik. Ini antara lain disebabkan oleh perbedaan latar belakang budaya. Dikatakan Mulyana (2001:197) perbedaan aspek budaya seperti kepercayaan, nilai, sikap, pandangan dunia, organisasi sosial, tabiat manusia, orientasi kegiatan, dan konsep diri atau tanggapan tentang diri dan orang lain akan mewarnai persepsi dan prasangka terhadap keberadaan dan perilaku orang lain.

Mengkaji aspek komunikasi khususnya yang berkaitan dengan persepsi, dan prasangka antaretnik yang diwarnai budaya yang berbeda penting dilakukan, karena dengan penelitian yang mendalam persepsi dan prasangka buruk antaretnik dapat dipahami dan secepatnya dicarikan model pemecahannya secara ilmiah, sehingga konflik antaretnik yang disebabkan oleh benturan budaya seperti yang pernah terjadi di daerah lain Sampit, Poso, Ambon dan lain-lain di Lampung hal itu bisa dihindari. Penelitian ini bertujuan mendeskripsikan persepsi dan prasangka antar etnik Sunda, Jawa, Batak, Lampung dan Sulawesi di Bakauheni Kalianda Lampung Selatan.

\section{PENDEKATAN DAN METODE PENELITIAN}

Untuk mendeskripsikan dan memahami fenomena yang dijadikan fokus penelitian digunakan pendekatan kualitatif. Pendekatan kualitatif termasuk dalam naturalistic inquiry, yang memperlakukan manusia sebagai instrumen karena penelitiannya sarat oleh muatan naturalistik. Pendekatan kualitatif sebagai prosedur penelitian dalam penelitian ini akan menghasilkan data deskriptif berupa kata-kata tertulis atau lisan dari orang-orang dan perilaku yang diamati. Peneliti sebagaimana dijelaskan Creswell (2002:4) membangun gambaran yang kompleks dan holistik, melalukan analisis kata-kata, melaporkan pandangan informan secara 
terinci dan melakukan penelitian dalam tataran alamiah. Dapat disimpulkan bahwa pendekatan kualitatif yang digunakan dalam penelitian ini bersifat deskriptrif. Metode deskriptif sebagaimana dikatakan Nazir (1998:63) bertujuan membuat deskripsi, gambaran, lukisan secara sistematik, faktual, akurat tentang fakta, sifat, juga hubungan antar fenomena yang diselidiki.

Adapun metode pengumpulan data dalam penelitian ini selain ditempuh melalui wawancara terhadap lima puluh informan juga didukung oleh data sekunder berupa bahan literatur yang erat kaitannya dengan masalah penelitian. Terkait dengan bagaimana peneliti melakukan aktivitas pengumpulan data, peneliti mengacu pada aktivitas rujukan pengumpulan data yang disarankan Creswell yang disebut dengan "A Data Collection Circle'(Creswell,1988:109-35). Model Creswell ini dibagankan berikut :

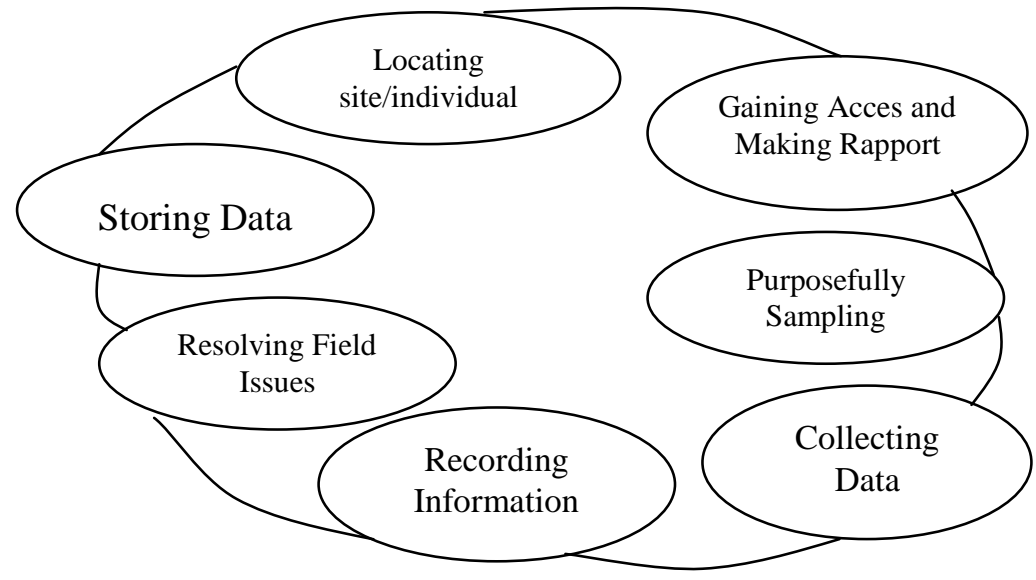

\section{HASIL DAN PEMBAHASAN}

\section{Persepsi Antaretnik Lampung, Bugis, Batak, Sunda dan Jawa di Bakauheni}

Persepsi Etnik Lampung terhadap Etnik Bugis, Batak, Sunda dan Jawa

Persepsi etnik Lampung terhadap ciri-ciri etnik lain yakni etnik Bugis, Batak, Sunda dan Jawa dapat dilihat pada tabel 1 .

Tabel 1. di atas menunjukkan bahwa $70 \%$ responden etnik Lampung berpersepsi terhadap orang Bugis sebagai sosok yang "berani", "jujur", "giat", dan "agamis". Sementara $60 \%$ dari mereka berpersepsi bahwa orang Bugis "bijaksana", "pandai" alias berpendidikan, dan relatif "moderen" atau tidak terlampau terikat pada adat istiadatnya. Terhadap orang Batak, responden etnik Lampung sebanyak (90\%) berpersepsi bahwa orang Batak sebagai sosok "pemaaf" atau tidak pendendam. Selain itu, sebanyak $80 \%$ mereka berpersepsi orang Batak "berani" berbicara apa adanya, berani mempertahankan prinsif, "pandai" alias berpendidikan, dan "giat" bekerja. Di samping itu, 60\% mereka berpersepsi bahwa 
orang Batak "moderen" atau tidak terlalu terikat dengan adat istiadat daerahnya, dan "terbuka" terbiasa hidup berdampingan dengan orang lain.

Tabel 1. Persepsi Etnik Lampung terhadap Etnik Bugis, Batak, Sunda dan Jawa

\begin{tabular}{lllll}
\hline Prilaku & Bugis & Batak & Sunda & Jawa \\
\hline Berani & $70 \%$ & $80 \%$ & $40 \%$ & $40 \%$ \\
Rendah hati & $30 \%$ & $10 \%$ & $80 \%$ & $90 \%$ \\
Toleran & $40 \%$ & $30 \%$ & $70 \%$ & $80 \%$ \\
Jujur & $70 \%$ & $30 \%$ & $50 \%$ & $70 \%$ \\
Halus/lembut & $30 \%$ & - & $90 \%$ & $100 \%$ \\
Bijaksana & $60 \%$ & $10 \%$ & $50 \%$ & $80 \%$ \\
Pandai & $60 \%$ & $80 \%$ & $60 \%$ & $60 \%$ \\
Pemurah & $50 \%$ & $50 \%$ & $50 \%$ & $60 \%$ \\
Moderen & $60 \%$ & $60 \%$ & $60 \%$ & $50 \%$ \\
Sederhana & $40 \%$ & $30 \%$ & $60 \%$ & $70 \%$ \\
Giat & $70 \%$ & $80 \%$ & $40 \%$ & $80 \%$ \\
Agamis & $70 \%$ & $40 \%$ & $70 \%$ & $50 \%$ \\
Terbuka & $30 \%$ & $60 \%$ & $60 \%$ & $70 \%$ \\
Pemaaf & $40 \%$ & $90 \%$ & $80 \%$ & $80 \%$ \\
\hline
\end{tabular}

Kemudian terhadap etnik Sunda utamanya Sunda Priangan etnik Lampung (90\%) berpersepsi bahwa etnik Sunda sebagai sosok manusia yang "halus" bahasa dan prilakunya. Mereka juga sebanyak $80 \%$ berpersepsi etnik Sunda sebagai "rendah hati" tidak biasa menonjolkan diri, dan bersifat "pemaaf". Etnik Sunda juga dipersepsi responden etnik Lampung (70\%) sebagai etnik yang "agamis" atau kuat memegang prinsif agama dan "toleran" terhadap keberadaan orang lain. Di samping itu $60 \%$ dari mereka pun berpersepsi bahwa orang Sunda termasuk "pandai" atau relatif berpendidikan, "sederhana", "terbuka" tidak hidup eklusif, dan "moderen" tidak terlalu terikat dengan adat istiadatnya.

Tidak jauh berbeda terhadap etnik Sunda, etnik Lampung sebanyak 100\% berpersepsi terhadap etnik Jawa sebagai sosok yang "halus" bahasa dan prilakunya. Mereka juga sebanyak $90 \%$ berpersepsi bahwa etnik Jawa sebagai sosok yang "rendah hati" tidak biasa menonjolkan diri. Sementara sebanyak $80 \%$ mereka berpersepsi bahwa etnik Jawa adalah etnik yang "toleran", " bijaksana", "pemaaf," dan "giat" bekerja. Di samping itu, 70\% mereka juga berpersepsi bahwa orang Jawa "sederhana", "jujur" dan "terbuka" hidupnya, dan $60 \%$ dari mereka pun berpandangan bahwa etnik Jawa termasuk "pandai" atau berpendidikan, dan "pemurah".

Persepsi etnik Lampung terhadap ciri yang menonjol dari etnik Bugis sebagai sosok "berani" sesuai dengan persepsi orang Batak sebagaimana dikemukakan Schweizer dalam Mulyana (2000:218). Demikian juga ciri dominan "giat" bekerja yang dipersepsi etnik Lampung terhadap orang Batak sejalan dengan hasil penelitian tersebut. Persepsi etnik Lampung terhadap orang Jawa sebagai "halus" pembawaan, "rendah hati atau ramah ", sejalan dengan persepsi orang 
Bugis dan Batak yang dikemukakan Schweizer. Ini juga tampaknya ada kaitannya dengan prinsif kearifan orang Jawa yang dikemukakan Amrih (2008:94) dengan istilah wani ngalah dhuwur wekasane atau kudu andap asor bahwa orang Jawa itu berusaha menang tanpa merasa atau dirasakan mengalahkan orang lain.

Persepsi Etnik Batak terhadap Etnik Bugis, Sunda, Jawa dan Lampung

Persepsi etnik Batak terhadap ciri-ciri etnik lain yakni etnik Bugis, Sunda, Jawa dan Lampung dapat dilihat pada tabel berikut :

Tabel 2. Persepsi Etnik Batak terhadap Etnik Bugis, Sunda, Jawa dan Lampung

\begin{tabular}{lllll}
\hline Prilaku & Bugis & Sunda & Jawa & Lampung \\
\hline Berani & $100 \%$ & $40 \%$ & $40 \%$ & $100 \%$ \\
Rendah hati & $40 \%$ & $90 \%$ & $100 \%$ & $40 \%$ \\
Toleran & $80 \%$ & $100 \%$ & $100 \%$ & $40 \%$ \\
Jujur & $70 \%$ & $80 \%$ & $90 \%$ & $60 \%$ \\
Halus/lembut & $30 \%$ & $100 \%$ & $100 \%$ & - \\
Bijaksana & $70 \%$ & $60 \%$ & $100 \%$ & $40 \%$ \\
Pandai & $60 \%$ & $60 \%$ & $60 \%$ & $60 \%$ \\
Pemurah & $40 \%$ & $60 \%$ & $90 \%$ & $20 \%$ \\
Moderen & $70 \%$ & $80 \%$ & $70 \%$ & $50 \%$ \\
Sederhana & $40 \%$ & $30 \%$ & $100 \%$ & $80 \%$ \\
Giat & $60 \%$ & $20 \%$ & $80 \%$ & $20 \%$ \\
Agamis & $70 \%$ & $90 \%$ & $90 \%$ & $90 \%$ \\
Terbuka & $60 \%$ & $40 \%$ & $90 \%$ & $30 \%$ \\
Pemaaf & $60 \%$ & $100 \%$ & $100 \%$ & $60 \%$ \\
\hline
\end{tabular}

Persepsi etnik Batak terhadap etnik lain (outgroup) sesuai dengan data pada tabel di atas menunjukkan bahwa $100 \%$ responden orang Batak berpersepsi terhadap ciri orang Bugis sebagai sosok yang "berani" mempertahankan prinsif atau mengambil resiko hidup. Keberanian orang Bugis menurut mereka nampak seperti keberanian dalam mengarungi lautan jadi nelayan. Demikian pula $80 \%$ dari responden Batak berpersepsi bahwa orang Bugis termasuk "toleran" dan 70\% mereka berpersepsi bahwa orang Bugis sebagai orang yang "jujur", "bijaksana" "agamis" dan "moderen". Selebihnya 60 \% dari mereka berpersepsi bahwa orang Bugis adalah sosok yang " pandai" atau berpendidikan, "giat" bekerja, "terbuka" dan " pemaaf".

Kemudian terhadap orang Sunda, etnik Batak sebanyak (100 \%) berpersepsi bahwa orang Sunda lebih-lebih Sunda Priangan adalah sosok yang "toleran," "halus" tutur sapa dan prilakunya dan "pemaaf" atau tidak pendendam. Demikian juga sebanyak $90 \%$ mereka berpersepsi bahwa orang Sunda "rendah hati" dan "agamis", dan 80\% mereka berpersepsi bahwa orang Sunda "jujur" dan "moderen" tidak terlampau terikat adat istiadatnya. Sementara 60\% dari mereka berpersepsi orang Sunda "bijaksana", "pandai", dan "pemurah". Tidak jauh berbeda terhadap etnik Sunda, etnik Batak sebanyak 100\% berpersepsi terhadap etnik Jawa sebagai sosok yang "rendah hati", "toleran", "halus lembut" tutur sapanya, "bijaksana", 
"sederhana" hidupnya dan "pemaaf". Mereka juga sebanyak $90 \%$ berpersepsi bahwa etnik Jawa sebagai sosok yang "jujur", "pemurah", "terbuka" mudah diajak bermusyawarah, "pemaaf", dan "agamis" alias teguh memegang ajaran agama. Demikian juga etnik Jawa dipersepsi responden etnik Batak $(80 \%)$ sebagai etnik yang "giat" bekerja. Selebihnya $70 \%$ dari mereka beranggapan bahwa orang Jawa "moderen" atau tidak terlalu terikat dengan adat tradisinya dan $60 \%$ dari mereka berpersepsi orang Jawa sebagai orang yang "pandai" atau berpendidikan.

Adapun terhadap orang Lampung responden etnik Batak 100\% berpersepsi bahwa orang Lampung termasuk "berani" berbicara apa adanya, dan berani memperjuangan serta mempertahankan prinsif dan harga dirinya meski harus berkonflik dengan orang lain. Di samping itu, $90 \%$ dari mereka berpersepsi orang Lampung "agamis" atau taat beragama. Demikian juga, 80\% mereka menganggap orang Lampung " sederhana " pola hidupnya. Sementara $60 \%$ dari mereka pun berpersepsi orang Lampung "pemaaf", "pandai", dan "jujur". Selebihnya, 50\% responden Batak menganggap orang Lampung "moderen" atau tidak terlalu terikat dengan adat tradisinya. .

Persepsi etnik Batak terhadap ciri yang menonjol dari etnik Bugis sebagai sosok "berani" sesuai dengan persepsi orang Jawa sebagaimana dikemukakan temuan penelitian Schweizer dalam Mulyana (2000:218). Demikian juga ciri dominan "halus", yang dipersepsi etnik Batak terhadap orang Jawa sejalan dengan hasil penelitian tersebut. Persepsi etnik Batak terhadap orang Jawa sebagai "halus" pembawaan, "rendah hati atau ramah", sejalan dengan persepsi orang Bugis yang dikemukakan Schweizer. Ini juga tampaknya ada kaitannya dengan prinsif kearifan orang Jawa yang dikemukakan Amrih (2008:94) dengan istilah kudu andap asor bahwa orang Jawa itu haruslah rendah hati.

\section{Persepsi Etnik Sunda terhadap Etnik Bugis, Batak, Jawa dan Lampung}

Persepsi etnik Sunda terhadap ciri-ciri etnik lain yakni etnik Bugis, Batak, Jawa dan Lampung dapat dilihat pada tabel 3.

Persepsi etnik Sunda terhadap etnik lain (outgroup) sesuai dengan data pada tabel di atas menunjukkan bahwa $100 \%$ responden orang Sunda berpersepsi terhadap orang Bugis sebagai sosok yang "jujur", "pandai" alias berpendidikan, "giat" bekerja, "agamis" atau taat beragama dan "berani" menghadapi resiko hidup seperti mengarungi lautan menjadi nelayan dan berani membela harga diri dan berbicara apa adanya meski bertentangan dengan orang lain. $80 \%$ dari mereka juga berpersepsi bahwa orang Bugis "terbuka" atau bisa menerima keberadaan orang lain, dan $70 \%$ dari mereka berpersepsi bahwa orang Bugis pun termasuk "pemurah". Kemudian terhadap orang Batak, etnik Sunda sebanyak (100\%) berpersepsi bahwa orang Batak termasuk "berani" membela prinsif hidupnya, serta berani berbicara apa adanya meski bertentangan dengan pendapat orang lain. Demikian juga, sebanyak $90 \%$ mereka berpersepsi bahwa orang Batak termasuk "pandai" atau berpendidikan, "pemurah", "pemaaf" dan "agamis", dan sebanyak $80 \%$ mereka berpersepsi bahwa orang Batak termasuk "giat" bekerja dan "terbuka" untuk berdampingan hidup dengan etnik lain. Merekapun sebanyak 70\% 
berpersepsi bahwa orang Batak termasuk "moderen" atau tidak terlampau terikat pada adat tradisinya.

Tabel 3. Persepsi Etnik Sunda terhadap Etnik Bugis, Batak, Jawa dan Lampung

\begin{tabular}{lllll}
\hline Prilaku & Bugis & Batak & Jawa & Lampung \\
\hline Berani & $100 \%$ & $100 \%$ & $100 \%$ & $100 \%$ \\
Rendah hati & $10 \%$ & $20 \%$ & $100 \%$ & $10 \%$ \\
Toleran & $20 \%$ & $30 \%$ & $100 \%$ & $10 \%$ \\
Jujur & $100 \%$ & $30 \%$ & $100 \%$ & $20 \%$ \\
Halus/lembut & $20 \%$ & $10 \%$ & $100 \%$ & $30 \%$ \\
Bijaksana & $40 \%$ & $30 \%$ & $100 \%$ & $20 \%$ \\
& & & & \\
Pandai & $100 \%$ & $90 \%$ & $100 \%$ & $90 \%$ \\
Pemurah & $70 \%$ & $90 \%$ & $70 \%$ & $10 \%$ \\
Moderen & $40 \%$ & $70 \%$ & $70 \%$ & $20 \%$ \\
Sederhana & $20 \%$ & $20 \%$ & $100 \%$ & $20 \%$ \\
Giat & $100 \%$ & $80 \%$ & $100 \%$ & $10 \%$ \\
Agamis & $100 \%$ & $90 \%$ & $40 \%$ & $70 \%$ \\
Terbuka & $80 \%$ & $80 \%$ & $90 \%$ & $90 \%$ \\
Pemaaf & $10 \%$ & $90 \%$ & $80 \%$ & $10 \%$ \\
\hline
\end{tabular}

Terhadap etnik Jawa, etnik Sunda sebanyak $100 \%$ berpersepsi bahwa orang Jawa termasuk sosok yang "berani" mempertahankan harga diri atau prinsif hidup, "rendah hati", "toleran","jujur"," halus lembut" tutur sapanya, "bijaksana", "pandai" atau berpendidikan, "sederhana" dan " giat" bekerja. Mereka juga sebanyak $90 \%$ berpersepsi bahwa etnik Jawa sebagai sosok yang "terbuka" berdampingan hidup dengan etnik lain dan mudah diajak bermusyawarah. Demikian juga etnik Jawa dipersepsi responden etnik Sunda (80\%) sebagai etnik yang "moderen" atau tidak terlampau terikat tradisi dan juga "pemaaf". Selebihnya 70\% responden etnik Sunda berpersepsi bahwa orang Jawa sebagai orang yang "pemurah" dan "moderen".

Terhadap orang Lampung responden etnik Sunda sebanyak $100 \%$ menganggap bahwa orang Lampung sebagi orang yang "berani" mempertahankan dan memperjuangkan harga diri atau prinsif hidup dan berani berbicara apa adanya meski bertentangan dengan pendapat orang lain. Disamping itu, sebanyak $90 \%$ mereka berpersepsi bahwa orang Lampung termasuk "terbuka" atau terbiasa menerima kehadiran etnik lain, dan relatif "pandai" atau berpendidikan. $70 \%$ dari responden Sunda pun berpersespi bahwa orang Lampung termasuk "agamis" alias kuat memegang ajaran agama .

Persepsi etnik Sunda terhadap ciri yang menonjol dari etnik Batak sebagai sosok "berani" sesuai dengan persepsi orang Jawa sebagaimana dikemukakan temuan penelitian Schweizer dalam Mulyana (2000:218). Ciri lain yang dominan yang dipersepsi orang Sunda terhadap etnik Batak yakni suka bekerja keras atau "giat" bekerja. Hal ini sebagaimana dikemukakan Antonius Simanjuntak (2009: 
142) sesuai dengan nilai budaya Batak bahwa orang Batak sangat menghargai kekayaan (hamoraon), disamping keturunan (hagabeon) dan kehormatan atau martabat ( hasangapon). Kekayaan sejatinya hanya bisa diperoleh dengan bekerja keras. Kemudian ciri dominan "halus", yang dipersepsi etnik Sunda terhadap orang Jawa sebagaimana telah dikemukakan hal ini juga tampaknya ada kaitannya dengan prinsif kearifan orang Jawa yang dikemukakan Amrih (2008:94) dengan istilah kudu andap asor bahwa orang Jawa itu haruslah rendah hati. Persepsi etnik Sunda terhadap orang Bugis sebagai orang yang "berani" pun sejalan dengan persepsi orang Batak yang dikemukakan Schweizer dalam temuan penelitiannya.

Persepsi Etnik Bugis terhadap Etnik Batak, Sunda, Jawa dan Lampung

Persepsi etnik Bugis terhadap ciri-ciri etnik lain yakni etnik Batak, Sunda, Jawa dan Lampung dapat dilihat pada tabel berikut :

Tabel 4. Persepsi Etnik Bugis terhadap Etnik Batak, Sunda, Jawa dan Lampung

\begin{tabular}{lllll}
\hline Prilaku & Batak & Sunda & Jawa & Lampung \\
\hline Berani & $100 \%$ & $70 \%$ & $80 \%$ & $100 \%$ \\
Rendah hati & - & $80 \%$ & $100 \%$ & - \\
Toleran & $80 \%$ & $90 \%$ & $100 \%$ & $80 \%$ \\
Jujur & $70 \%$ & $100 \%$ & $100 \%$ & $80 \%$ \\
Halus/lembut & - & $100 \%$ & $100 \%$ & $10 \%$ \\
Bijaksana & $80 \%$ & $90 \%$ & $100 \%$ & $70 \%$ \\
Pandai & $100 \%$ & $100 \%$ & $100 \%$ & $80 \%$ \\
Pemurah & $100 \%$ & $90 \%$ & $80 \%$ & $80 \%$ \\
Moderen & $20 \%$ & $30 \%$ & $10 \%$ & $10 \%$ \\
Sederhana & $70 \%$ & $100 \%$ & $100 \%$ & $20 \%$ \\
Giat & $100 \%$ & $80 \%$ & $100 \%$ & $40 \%$ \\
Agamis & $100 \%$ & $100 \%$ & $100 \%$ & $100 \%$ \\
Terbuka & $100 \%$ & $90 \%$ & $90 \%$ & $80 \%$ \\
Pemaaf & $80 \%$ & $90 \%$ & $90 \%$ & $70 \%$ \\
\hline
\end{tabular}

Tabel di atas menunjukkan bahwa 100\% responden etnik Bugis berpersepsi terhadap orang Batak sebagai sosok yang "berani" mempertahankan harga diri dan berani berbicara apa adanya, mereka juga dipersepsi "pandai" alias berpendidikan, "giat" bekerja "agamis", "pemurah" dan "terbuka" untuk berdampingan hidup dengan etnik lain. Responden Bugis juga $80 \%$ berpersepsi bahwa orang Batak termasuk "toleran", "bijaksana", dan " pemaaf". Disamping itu, 70\% dari mereka berpersepsi orang Batak "jujur" dan "sederhana". Kemudian terhadap orang Sunda, etnik Bugis sebanyak (100\%) berpersepsi bahwa orang Sunda termasuk" jujur", "halus", "pandai" alias berpendidikan, "sederhana" dan "agamis" atau kuat memegang ajaran agama. Demikian juga sebanyak $90 \%$ mereka berpersepsi bahwa orang Sunda termasuk "toleran", "bijaksana," "pemurah", "pemaaf" dan "terbuka" menerima kehadiran orang lain, dan sebanyak 
$80 \%$ mereka berpersepsi bahwa orang Sunda termasuk "giat" bekerja dan "rendah hati". Merekapun sebanyak $70 \%$ berpersepsi bahwa orang Sunda termasuk "berani" mempertahankan harga diri atau prinsif hidupnya.

Terhadap etnik Jawa, etnik Bugis sebanyak $100 \%$ berpersepsi bahwa orang Jawa termasuk sosok yang "rendah hati", "toleran","jujur","halus lembut" tutur sapanya, "bijaksana", "pandai" atau berpendidikan, "sederhana", "giat" bekerja dan "agamis". Mereka juga sebanyak $90 \%$ berpersepsi bahwa etnik Jawa sebagai sosok yang "terbuka" mudah diajak bermusyawarah, dan mudah menerima kehadiran orang lain dan "pemaaf". Demikian juga etnik Jawa dipersepsi responden etnik Bugis (80\%) sebagai etnik yang "pemurah" dan "berani" mengambil resiko dalam mempertahankan prinsif hidupnya. Sementara terhadap orang Lampung, responden etnik Bugis sebanyak $100 \%$ menganggap orang Lampung sebagi orang yang "berani" mempertahankan harga diri, berani berbicara apa adanya, dan "agamis" alias kuat memegang ajaran agamanya. Orang Lampung dipersepsi etnik Bugis sebagai orang yang "berani" hal ini sejalan dengan prinsif hidup orang lampung yakni piil pesenggiri. Piil pesenggiri adalah perangai yang keras yang tidak mau mundur terhadap tindakan dengan kekerasan, lebihlebih menyangkut ketersingungan nama, baik keturunan, kehormatan pribadi, kerabat atau rasa harga diri ( Nurdin, 2009:44). Di samping "berani" dan "agamis" sebanyak $80 \%$ responden etnik Bugis berpersepsi bahwa orang Lampung juga termasuk "pandai" atau berpendidikan, "pemurah", dan "terbuka" menerima kehadiran orang lain, dan $70 \%$ dari mereka berpersepsi bahwa orang Lampung termasuk "bijaksana" dan "pemaaf". 60 \% dari merekapun berpersepsi bahwa orang Lampung "jujur".

\section{Persepsi Etnik Jawa terhadap Etnik Bugis, Batak, Sunda, dan Lampung}

Persepsi etnik Jawa terhadap ciri-ciri etnik lain yakni etnik Bugis, Batak, Sunda, dan Lampung dapat dilihat pada tabel 5.

Tabel 5. menunjukkan bahwa $100 \%$ responden etnik Jawa berpersepsi terhadap orang Bugis sebagai sosok yang "berani" sebagai pelaut atau nelayan yang penuh resiko, berani berkonflik jika perlu untuk mempertahankan prinsif, dan "jujur". Persepsi etnik Jawa terhadap ciri yang menonjol dari etnik Bugis sebagai sosok "berani" sesuai dengan persepsi orang Batak sebagaimana dikemukakan temuan penelitian Schweizer dalam Mulyana (2000:218). Responden Etnik Jawa juga $80 \%$ berpersepsi bahwa orang Bugis termasuk "giat" bekerja, dan "agamis" dan sebanyak $70 \%$ mereka berpersepsi orang Bugis "bijaksana", "pandai" atau berpendidikan, dan "pemaaf". Merekapun $60 \%$ berpersepsi bahwa orang Bugis, "moderen" atau tidak terlampau terikat dengan adat istiadat daerah asalnya. Kemudian terhadap orang Batak, responden etnik Jawa sebanyak (100\%) berpersepsi bahwa orang Batak termasuk" berani" berbicara apa adanya, dan berani berkonflik mempertahankan prinsifnya dan "pandai" alias berpendidikan, serta "pemaaf" jauh dari rasa dendam. Demikian juga sebanyak $80 \%$ mereka berpersepsi bahwa orang Batak termasuk "jujur", dan "terbuka" menerima kehadiran orang lain, dan sebanyak $70 \%$ mereka berpersepsi bahwa orang Batak termasuk "giat" bekerja. Merekapun sebanyak $60 \%$ berpersepsi bahwa orang 
Batak pun termasuk "bijaksana" dan "moderen" atau tidak terlalu terikat dengan tradisinya. Di samping itu, 50\% responden etnik Jawa berpersepsi bahwa orang Batak termasuk "agamis" atau taat beragama.

Tabel 5. Persepsi Etnik Jawa terhadap Etnik Bugis, Batak, Sunda dan Lampung

\begin{tabular}{lllll}
\hline Prilaku & Bugis & Batak & Sunda & Lampung \\
\hline Berani & $100 \%$ & $100 \%$ & $70 \%$ & $90 \%$ \\
Rendah hati & $10 \%$ & - & $100 \%$ & $10 \%$ \\
Toleran & $20 \%$ & $10 \%$ & $100 \%$ & $20 \%$ \\
Jujur & $100 \%$ & $80 \%$ & $90 \%$ & $50 \%$ \\
Halus/lembut & $10 \%$ & - & $80 \%$ & - \\
Bijaksana & $70 \%$ & $60 \%$ & $90 \%$ & $50 \%$ \\
Pandai & $70 \%$ & $100 \%$ & $100 \%$ & $70 \%$ \\
Pemurah & $40 \%$ & $40 \%$ & $50 \%$ & $30 \%$ \\
Moderen & $60 \%$ & $60 \%$ & $60 \%$ & $60 \%$ \\
Sederhana & $20 \%$ & $10 \%$ & $60 \%$ & $20 \%$ \\
Giat & $80 \%$ & $80 \%$ & $80 \%$ & $10 \%$ \\
Agamis & $80 \%$ & $50 \%$ & $90 \%$ & $80 \%$ \\
Terbuka & $20 \%$ & $90 \%$ & $70 \%$ & $20 \%$ \\
Pemaaf & $70 \%$ & $100 \%$ & $90 \%$ & $20 \%$ \\
\hline
\end{tabular}

Terhadap etnik Sunda etnik Jawa sebanyak $100 \%$ berpersepsi bahwa orang Sunda termasuk sosok yang "rendah hati", "toleran"," dan "pandai" atau relatif berpendidikan. "bijaksana", "pemaaf" dan "agamis" alias taat menjalankan agama Islam. Demikian juga orang Sunda dipersepsi responden etnik Jawa $(80 \%)$ sebagai etnik yang "halus" bertutur sapa, "giat" bekerja, "terbuka" dan "berani" memperjuangkan harga diri dan prinsif hidupnya. Selebihnya, sebanyak $60 \%$ mereka berpersepsi orang Sunda "sederhana" dalam hidup dan "moderen" alias tidak terlalu terikat dengan adat istiadat daerahnya, dan 50\% dari mereka beranggapan bahwa orang Sunda termasuk "pemurah". Sementara terhadap orang Lampung responden etnik Jawa sebanyak 90\% menganggap orang Lampung sebagi orang yang "berani" mempertahankan harga diri dan prinsif hidupnya, berani berbicara apa adanya meski bertentangan dengan orang lain. Sebanyak 80 $\%$ mereka pun berpersepsi bahwa orang Lampung termasuk "agamis", atau taat beragama, dan $70 \%$ dari mereka berpersespi bahwa orang Lampung termasuk " pandai" atau relatif berpendidikan, dan $60 \%$ responden etnik Jawa berpersepsi bahwa orang Lampung pun "moderen" atau tidak terlalu terikat dengan adat istiadatnya. Selain itu, 50\% dari mereka berpersepsi bahwa orang Lampung "jujur" dan " bijaksana". 


\section{Prasangka Antaretnik Lampung, Bugis, Batak, Sunda dan Jawa di Bakauheni}

\section{Prasangka Etnik Lampung terhadap Etnik Bugis, Batak, Sunda dan Jawa}

Prasangka etnik Lampung terhadap ciri-ciri etnik lain yakni etnik Bugis, Batak, Sunda, dan Jawa dapat dilihat pada tabel berikut:

Tabel 6. Prasangka Etnik Lampung terhadap Etnik Bugis, Batak, Sunda, Jawa.

\begin{tabular}{lllll}
\hline Prilaku & Bugis & Batak & Sunda & Jawa \\
\hline Penakut & $30 \%$ & $20 \%$ & $60 \%$ & $60 \%$ \\
Angkuh & $70 \%$ & $90 \%$ & $20 \%$ & $10 \%$ \\
Egois & $60 \%$ & $70 \%$ & $30 \%$ & $20 \%$ \\
Pembohong & $30 \%$ & $70 \%$ & $50 \%$ & $30 \%$ \\
Kasar & $70 \%$ & $100 \%$ & $10 \%$ & - \\
Licik & $40 \%$ & $90 \%$ & $50 \%$ & $20 \%$ \\
Bodoh & $40 \%$ & $20 \%$ & $40 \%$ & $40 \%$ \\
Kikir & $50 \%$ & $50 \%$ & $50 \%$ & $40 \%$ \\
Feodal & $40 \%$ & $40 \%$ & $40 \%$ & $50 \%$ \\
Boros & $60 \%$ & $70 \%$ & $40 \%$ & $30 \%$ \\
Pemalas & $30 \%$ & $20 \%$ & $60 \%$ & $20 \%$ \\
Sekuler & $30 \%$ & $60 \%$ & $30 \%$ & $50 \%$ \\
Tertutup & $70 \%$ & $40 \%$ & $40 \%$ & $30 \%$ \\
Pendendam & $60 \%$ & $10 \%$ & $20 \%$ & $20 \%$ \\
\hline
\end{tabular}

Berkenaan dengan perasangka etnik Lampung terhadap etnik lain (outgroup) sesuai dengan data pada tabel di atas menunjukkan bahwa responden etnik Lampung 70 \% berprasangka terhadap orang Bugis sebagai sosok yang "angkuh", tidak rendah hati seperti etnik Jawa dan Sunda, serta "kasar" bahasa dan perilakunya dan "tertutup" alias hidup mengelompok. Selain itu responden etnik Lampung $60 \%$ berprasangka terhadap etnik Bugis sebagai sosok yang "egois" mau menang sendiri (sukuisme) " boros", dan " pendendam'. 50\% mereka pun berprasangka orang Bugis "kikir". Terhadap etnik Batak, responden etnik Lampung $100 \%$ berprasangka bahwa orang Batak sebagai sosok yang "kasar" bahasa dan prilakunya. Di samping itu, sebanyak $90 \%$ mereka berprasangka bahwa etnik Batak "angkuh", dan "licik" alias tidak bijaksana. Demikian juga sebanyak 70\% mereka berperasangka bahwa etnik Batak "egois", "pembohong" atau tidak jujur, dan "boros". Demikian juga $60 \%$ responden etnik Lampung berprasangka bahwa orang Batak sekuler atau kurang taat beragam.

Adapun terhadap Etnik Sunda utamanya terhadap etnik Sunda Priangan responden etnik Lampung (60\%) berprasangka bahwa orang Sunda "penakut" tidak berani berbicara apa adanya, dan etnik Sunda pada umunya baik Sunda priangan maupun Sunda Banten "pemalas" tidak giat dan tidak ulet bekerja seperti halnya orang Jawa. Di samping itu, $50 \%$ dari mereka berprasangka orang Sunda sebagai "pembohong", "licik" dan "kikir". Kemudian terhadap etnik Jawa 60\% 
responden etnik Lampung berprasangka bahwa orang Jawa umumnya penakut tidak berani berbicara apa adanya, tidak berani bersifat frontal seperti halnya orang Batak, Lampung dan Bugis. Di samping itu, 50\% respponden etnik Lampung berprasangka bahwa orang Jawa "feodal" dan "sekuler.

Prasangka Etnik Batak terhadap Etnik Bugis, Sunda, Jawa dan Lampung

Prasangka etnik Batak terhadap ciri-ciri etnik lain yakni etnik Bugis, Sunda, dan Jawa dan Lampung dapat dilihat pada tabel berikut:

Tabel 7. Prasangka Etnik Batak terhadap Etnik Bugis, Sunda, Jawa dan Lampung

\begin{tabular}{lllll}
\hline Prilaku & Bugis & Sunda & Jawa & Lampung \\
\hline Penakut & - & $60 \%$ & $60 \%$ & - \\
Angkuh & $60 \%$ & $10 \%$ & - & $60 \%$ \\
Egois & $20 \%$ & - & - & $60 \%$ \\
Pembohong & $30 \%$ & $20 \%$ & $10 \%$ & $40 \%$ \\
Kasar & $70 \%$ & - & - & $100 \%$ \\
Licik & $30 \%$ & $40 \%$ & - & $60 \%$ \\
Bodoh & $40 \%$ & $40 \%$ & $40 \%$ & $40 \%$ \\
Kikir & $60 \%$ & $40 \%$ & $10 \%$ & $80 \%$ \\
Feodal & $30 \%$ & $20 \%$ & $30 \%$ & $50 \%$ \\
Boros & $60 \%$ & $70 \%$ & - & $20 \%$ \\
Pemalas & $40 \%$ & $80 \%$ & $20 \%$ & $80 \%$ \\
Sekuler & $30 \%$ & $10 \%$ & $10 \%$ & $10 \%$ \\
Tertutup & $40 \%$ & $60 \%$ & $10 \%$ & $70 \%$ \\
Pendendam & $40 \%$ & - & - & $40 \%$ \\
\hline \multicolumn{1}{l}{ Taber }
\end{tabular}

Tabel di atas menunjukkan bahwa responden etnik Batak sebanyak $70 \%$ berprasangka terhadap orang Bugis sebagai sosok yang "kasar" cara berbicara dan prilakunya. Demikian juga sebanyak $60 \%$ mereka menganggap orang Bugis sebagai sosok yang "boros" untuk kepentingan sendiri, namun "kikir" bagi orang lain, dan bersifat "angkuh". Adapun terhadap Etnik Sunda baik Sunda Priangan maupun Sunda Banten responden etnik Batak $(80 \%)$ berprasangka bahwa orang Sunda "pemalas" cepat berpuas diri, tidak ulet seperti halnya orang Jawa. Mereka juga $70 \%$ berprasangka bahwa etnik Sunda hidupnya "boros" tidak hemat. 60\% responden etnik Batak berprasangka bahwa orang Sunda pun hidupnya "tertutup" dan "penakut" atau tidak mau berterus terang bila mengemukakan sesuatu yang bertentangan dengan orang lain atau seolah penakut dalam membela prinsif hidupnya.

Tidak jauh berbeda dengan orang Sunda, sebanyak $60 \%$ responden etnik Batak juga berprasangka terhadap orang Jawa sebagai manusia "penakut" alias tidak berani berbicara apa adanya tidak berani membela prinsif hidup jika bertolakbelakang dengan orang lain. Kemudian terhadap orang Lampung $60 \%$ responden etnik Batak berprasangka bahwa orang Lampung umumnya "angkuh", "egois" dan "licik". Disamping itu 80\% responden etnik Batak berprasangka orang Lampung sebagai orang yang "kikir", dan "pemalas", dan 100 persen mereka 
menganggap orang Lampung sama dengan orang Batak "kasar" dalam berbicara dan berprilaku. Di samping itu, $70 \%$ responden Batak berprasangka bahwa orang Lampung "tertutup" atau inklusif hidupnya. Separuhnya yakni $50 \%$ etnik Batak berprasangka bahwa orang Lampung "feodal" alias kuat terikat dengan adat dan tradisinya.

Prasangka Etnik Sunda terhadap Etnik Bugis, Batak, Jawa dan Lampung

Prasangka etnik Sunda terhadap ciri-ciri etnik lain yakni etnik Bugis, Batak Jawa dan Lampung dapat dilihat pada tabel berikut:

Tabel 8. Prasangka Etnik Sunda terhadap Etnik Bugis, Batak, Jawa dan Lampung

\begin{tabular}{lllll}
\hline Prilaku & Bugis & Batak & Jawa & Lampung \\
\hline Penakut & - & - & - & - \\
Angkuh & $90 \%$ & $80 \%$ & - & $90 \%$ \\
Egois & $80 \%$ & $70 \%$ & - & $90 \%$ \\
Pembohong & - & $70 \%$ & - & $80 \%$ \\
Kasar & $80 \%$ & $90 \%$ & - & $70 \%$ \\
Licik & $60 \%$ & $70 \%$ & - & $80 \%$ \\
Bodoh & - & $10 \%$ & - & $10 \%$ \\
Kikir & $30 \%$ & $10 \%$ & $30 \%$ & $90 \%$ \\
Feodal & $60 \%$ & $30 \%$ & $30 \%$ & $80 \%$ \\
Boros & $80 \%$ & $80 \%$ & - & $80 \%$ \\
Pemalas & - & $20 \%$ & - & $90 \%$ \\
Sekuler & - & $10 \%$ & $60 \%$ & $30 \%$ \\
Tertutup & $20 \%$ & 20 & $10 \%$ & $10 \%$ \\
Pendendam & $90 \%$ & $10 \%$ & $20 \%$ & $90 \%$ \\
\hline
\end{tabular}

Tabel di atas menunjukkan bahwa responden etnik Sunda sebanyak $90 \%$ berprasangka terhadap orang Bugis sebagai sosok yang "angkuh" jauh dari rendah hati, dan "pendendam". Demikian juga sebanyak 80 \% mereka menganggap orang Bugis sebagai sosok yang "boros", "egois", alias mau menang sendiri, mudah emosi dan "kasar" atau reaktif. Demikian juga sebanyak 60\% mereka menganggap orang Bugis "licik" dan "feodal" alias terlalu terikat dengan tradisi etniknya sendiri. Adapun terhadap Etnik Batak, responden etnik Sunda (90\%) berprasangka bahwa orang Batak "kasar" dalam berbicara dan berprilaku tidak santun seperti halnya orang Jawa. Mereka juga 80 \% berprasangka bahwa orang Batak hidupnya "boros", suka mabuk-mabukan, dan "angkuh" jauh dari rendah hati. $70 \%$ responden etnik Sunda juga berprasangka bahwa orang Batak hidupnya "egois" atau mau menang sendiri, "pembohong" dan "licik" alias curang.

Terhadap orang jawa responden etnik Sunda $60 \%$ berprasangka bahwa orang Jawa sekuler alias kurang taat beragama. Kemudian terhadap orang Lampung $90 \%$ responden etnik Sunda berprasangka bahwa orang Lampung umumnya "angkuh", "egois", "kikir" atau pelit, "pemalas" dan "pendendam". Disamping itu, $80 \%$ responden etnik Sunda berprasangka terhadap orang Lampung sebagai orang 
yang "licik", "pembohong", "boros" dan "feodal" atau terlampau terikat pada adat tradisi., dan $70 \%$ mereka menganggap orang Lampung sama dengan orang Batak "kasar" dalam berbicara dan berprilaku.

Prasangka Etnik Bugis terhadap Etnik, Batak, Sunda, Jawa dan Lampung

Prasangka etnik Bugis terhadap ciri-ciri etnik lain yakni etnik Batak , Sunda, Jawa dan Lampung dapat dilihat pada tabel berikut:

Tabel 9. Prasangka Etnik Bugis terhadap Etnik Batak, Sunda, Jawa dan Lampung

\begin{tabular}{lllll}
\hline Prilaku & Batak & Sunda & Jawa & Lampung \\
\hline Penakut & - & $30 \%$ & $20 \%$ & - \\
Angkuh & $100 \%$ & $20 \%$ & - & $100 \%$ \\
Egois & $20 \%$ & $10 \%$ & - & $20 \%$ \\
Pembohong & $30 \%$ & - & - & $20 \%$ \\
Kasar & $100 \%$ & - & - & $90 \%$ \\
Licik & $20 \%$ & $10 \%$ & - & $30 \%$ \\
Bodoh & - & - & - & $20 \%$ \\
Kikir & - & $10 \%$ & $20 \%$ & $20 \%$ \\
Feodal & $80 \%$ & $70 \%$ & $90 \%$ & $90 \%$ \\
Boros & $30 \%$ & - & - & $80 \%$ \\
Pemalas & - & $20 \%$ & - & $60 \%$ \\
Sekuler & - & - & - & - \\
Tertutup & - & $10 \%$ & $10 \%$ & $20 \%$ \\
Pendendam & $20 \%$ & $10 \%$ & $10 \%$ & $30 \%$ \\
\hline
\end{tabular}

Berkenaan dengan perasangka terhadap etnik lain (outgroup) sesuai dengan data pada tabel di atas menunjukkan bahwa responden etnik Bugis sebanyak $100 \%$ berprasangka terhadap orang Batak sebagai sosok yang "kasar" dan "angkuh" jauh dari rendah hati. Demikian juga sebanyak $80 \%$ mereka menganggap orang Batak sebagai sosok yang "feodal", atau terlampau terikat pada adat tradisi atau marganya. Adapun terhadap Etnik Sunda, responden etnik Bugis (70\%) berprasangka bahwa orang Sunda "feodal" alias terlalu terikat pada adat tradisi daerahnya. Terhadap etnik Jawa, responden Bugis, $90 \%$ berprasangka bahwa orang Jawa "feodal" atau amat terikat dengan adat istiadat daerahnya. Kemudian terhadap orang Lampung 100\% responden etnik Bugis berprasangka bahwa orang Lampung umumnya "angkuh", jauh dari rendah hati. Disamping itu $90 \%$ responden etnik Bugis berprasangka terhadap orang Lampung sebagai orang yang "kasar" tutur sapa dan prilakunya, dan mereka juga dianggap "feodal" atau terlampau terikat pada adat tradisinya. $80 \%$ mereka menganggap bahwa orang Lampung juga "boros" atau gampang menjual kekayaan seperti tanah dan lain-lainnya untuk kepentingan pesta seperti pernikahan dan pestapesta lainnya. Di samping itu $70 \%$ responden etnik Bugis berprasangka bahwa orang Lampung sebagai orang yang "egois", dan $60 \%$ dari merekapun berprasangka orang Lampung "pemalas" dalam bekerja dan berusaha. 
Prasangka Etnik Jawa terhadap Etnik, Bugis, Batak, Sunda dan Lampung

Prasangka etnik Jawa terhadap ciri-ciri etnik lain yakni etnik Bugis, Batak , Sunda, dan Lampung dapat dilihat pada tabel berikut:

Tabel 10. Prasangka Etnik Jawa terhadap Etnik Bugis, Batak, Sunda dan Lampung

\begin{tabular}{lllll}
\hline Prilaku & Bugis & Batak & Sunda & Lampung \\
\hline Penakut & - & - & $20 \%$ & $10 \%$ \\
Angkuh & $90 \%$ & $100 \%$ & - & $90 \%$ \\
Egois & $80 \%$ & $90 \%$ & - & $80 \%$ \\
Pembohong & - & $20 \%$ & $10 \%$ & $50 \%$ \\
Kasar & $90 \%$ & $100 \%$ & $20 \%$ & $100 \%$ \\
Licik & $30 \%$ & $40 \%$ & $10 \%$ & $50 \%$ \\
Bodoh & $30 \%$ & - & - & $30 \%$ \\
Kikir & $60 \%$ & $60 \%$ & $50 \%$ & $70 \%$ \\
Feodal & $40 \%$ & $40 \%$ & $40 \%$ & $40 \%$ \\
Boros & $80 \%$ & $90 \%$ & $40 \%$ & $80 \%$ \\
Pemalas & $20 \%$ & $30 \%$ & $20 \%$ & $90 \%$ \\
Sekuler & $20 \%$ & $50 \%$ & $10 \%$ & $20 \%$ \\
Tertutup & $80 \%$ & $20 \%$ & $20 \%$ & $80 \%$ \\
Pendendam & $30 \%$ & - & $10 \%$ & $90 \%$ \\
\hline
\end{tabular}

Berkenaan dengan perasangka terhadap etnik lain (outgroup) sesuai dengan data pada tabel di atas menunjukkan bahwa responden etnik Jawa sebanyak $90 \%$ berprasangka terhadap orang Bugis sebagai orang yang "angkuh" dan "kasar" temperamen tutur sapa dan prilakunya. Demikian juga sebanyak $80 \%$ mereka menganggap orang Bugis sebagai sosok yang "egois", "boros" hidupnya, dan "tertutup" alias hidup berkelompok. Di samping itu, mereka sebanyak $60 \%$ berprasangka orang Bugis "kikir" untuk orang lain. Terhadap Etnik Batak, responden etnik Jawa (90\%) berprasangka bahwa orang Batak "angkuh", dan " kasar" tutur sapa ekspresi dan prilakunya. Mereka juga $80 \%$ berprasangka orang Batak "egois" dan "boros" hidupnya. Di samping iitu, 60\% dari responden etnik Jawa menganggap orang Batak " kikir" alias pelit, dan $50 \%$ dari mereka pun menganggap orang batak "sekuler" alias kurang taat beragama.

Kemudian terhadap orang Sunda $50 \%$ responden etnik Jawa berprasangka bahwa orang Sunda termasuk "kikir" untuk orang lain. Selanjutnya terhadap etnik Lampung, responden etnik Jawa $100 \%$ berprasangka bahwa orang Lampung termasuk "kasar" tutur sapa dan prilakunya. Disamping itu, 80\% responden etnik Jawa berprasangka terhadap orang Lampung sebagai orang yang "egois", dan "boros" untuk diri dan keluarganya sendiri. Namun 70 \% mereka menganggap orang Lampung "kikir" untuk orang lain, dan $50 \%$ dari mereka menganggap orang Lampung "pembohong" dan "licik". 
Faktor yang Mewarnai Persepsi dan Prasangka Antaretnik Sunda, Jawa, Lampung, Bugis dan Batak di Bakauheni Lampung Selatan

Dari paparan temuan data di lapangan, menunjukkan bahwa aspek pengalaman seperti keseringan bergaul atau kedekatan antaretnik sangat mewarnai terhadap persepsi antaretnik itu sendiri. Responden dari etnik tertentu yang sering atau akrab bergaul dengan etnik di luar etniknya akan memiliki pandangan yang positif atau persepsi yang baik terhadap etnik tersebut. Sebaliknya, responden yang tidak memiliki pengalaman dan kedekatan pergaulan dengan etnik tertentu cenderung memiliki persepsi negatif atau prasangka terhadap etnik itu. Kedekatan pergaulan antaretnik bisa diikat oleh satu pekerjaan, satu organisasi, dan bisa juga oleh ikatan keluarga atau perkawinan silang. Responden Bugis yang beristri etnik Sunda misalnya akan memiliki persepsi yang baik terhadap etnik tersebut, dibanding responden Bugis yang tidak memiliki ikatan keluarga seperti itu. Demikian juga responden etnik Batak yang memiliki istri orang Jawa misalnya memiliki persepsi yang baik terhadap etnik tersebut dibandingkan orang Batak yang tidak memiliki istri seorang Jawa. Orang Jawa yang umumnya dipersepsikan negatif sebagai "penakut" oleh umunya orang Batak misalnya dipersepsi positif oleh responden Batak yang beristiri Jawa. Orang Jawa menurut responden Batak yang beristri orang Jawa ini bukanlah tipe penakut melainkan tidak biasa berbicara terus terang kalau sekiranya dapat menyinggung perasaan orang lain. Demikian halnya orang Jawa atau Sunda yang memiliki kedekatan pergaulan dengan orang Batak berpersepsi bahwa meskipun orang Batak berwatak "keras" dan "kasar", ia tetap baik hatinya. "Keras" dan "kasar" hanya cara berbicara saja, sementara persepsi responden Jawa atau Sunda yang tidak memiliki kedekatan pergaulan dengan orang Batak tetap berpersepsi negatif atau berprasangka bahwa orang Batak "keras dan kasar" dalam segala hal alias jauh dari sopan santun tutur sapa dan prilakunya.

Selain diwarnai oleh aspek pengalaman kedekatan pergaulan, persepsi dan prasangka juga diwarnai oleh tingkat pendidikan responden. Makin tinggi pendidikan responden makin berkurang persepsi yang buruk atau prasangka terhadap etnik lain di luar etniknya. Responden yang berpendidikan tingkat menengah (SLTA) ke atas relatif tidak memiliki persepsi yang buruk atau prasangka terhadap etnik di luar dirinya. Sebaliknya makin rendah pendidikan responden, maka makin besar persepsi negatif atau prasangka terhadap etnik lain. Responden yang berpendidikan menengah ke atas misalnya umumnya menafsirkan ciri negatif yang ada pada seseorang bukan pada etniknya melainkan melekat pada pribadi orang yang bersangkutan. Sementara responden yang berpendidikan rendah dan kurang memiliiki pengalaman bergaul dengan etnik di luar dirinya umumnya menafsirkan bahwa ciri negatif melekat pada etnik tertentu bukan pada pribadi orangnya.

Selain diwarnai aspek pengalaman kedekatan pergaulan, dan tingkat pendidikan persepsi dan prasangka juga sangat diwarnai oleh status sosial. Seorang responden yang memiliki pekerja atau anak buah etnik tertentu cenderung menafsirkan bahwa etnik itu sebagai "bodoh" alias kurang berpendidikan. Demikian juga faktor agama ikut mewarnai persepsi dan prasangka 
antaretnik. Seorang yang beragama tertentu yang mengharamkan alkohol misalnya dapat dengan mudah berpersepsi negatif terhadap etnik lain yang beragama di luar dirinya yang menganggap bahwa etnik itu sebagai etnik yang suka meminum alkohol alias mabuk-mabukan.

Persepsi dan prasangka juga diwarnai oleh aspek pengalaman yang bersifat personal. Responden yang secara personal memiliki hubungan yang baik seperti pernah ditolong oleh etnik tertentu, memiliki persepsi atau pandangan positif terhadap etnik tersebut, meskipun responden lain pada umumnya menganggap etnik tersebut sebagai etnik yang "kikir" atau pelit terhadap orang lain. Hasil temuan penelitian ini menguatkan pendapat para ahli seperti apa yang dikemukkan Adam dan Fischer (dalam Karomani, 2009:75) bahwa persepsi antarmanusia antara lain sangat dipengaruhi oleh aspek pengalaman, dan aspek sosial budaya seperti agama, tingkat pendidikan, dan pekerjaan serta status sosial seseorang.

\section{KESIMPULAN}

1. Etnik Lampung, Bugis, Batak dan Sunda sebanyak $60 \%$ sampai di atas $60 \%$ umumnya berpersepsi sama terhadap tipikal etnik Jawa sebagai orang yang "halus atau lembut " tutur sapa dan prilakunya, "rendah hati", "toleran", "jujur", "giat bekerja", "bijak", "pandai" atau berpendidikan, "sederhana", "terbuka", "pemurah" dan pemaaf".

2. Terhadap etnik Sunda, etnik Lampung, Bugis, Batak dan Jawa sebanyak $60 \%$ sampai di atas $60 \%$ umumnya berpersepsi sama bahwa orang Sunda "halus" tutur sapa dan prilakunya, "rendah hati", "toleran", "pandai", "agamis" dan "pemaaf".

3. Terhadap etnik Bugis, etnik Lampung, Batak, Jawa dan Sunda sebanyak $60 \%$ sampai di atas $60 \%$ umumnya berpersepsi seragam bahwa orang Bugis umumnya "berani", "jujur", "pandai' dan "giat" bekerja.

4. Terhadap etnik Batak, etnik Lampung, Bugis, Sunda, dan Jawa sebanyak $60 \%$ sampai di atas $60 \%$ umumnya berpersepsi sama bahwa orang Batak umumnya "pemaaf", "berani", "pandai", "giat" bekerja dan "terbuka".

5. Terhadap etnik Lampung, etnik Bugis, Batak, Sunda dan Jawa sebanyak $60 \%$ sampai di atas $60 \%$ umumnya berpersepsi sama bahwa orang Lampung, "berani", dan "pandai" atau cukup berpendidikan.

6. Etnik Lampung, dan Batak $60 \%$ berprasangka bahwa etnik Jawa "penakut". Sementara etnik Bugis $90 \%$ berprasangka bahwa etnik Jawa "feodal" dan etnik Sunda $60 \%$ berprasangka orang Jawa "sekuler". Etnik Lampung $60 \%$ berprasangka orang Sunda "penakut" dan "pemalas". Sementara etnik Bugis berprasangka orang Sunda "feodal". Etnik Batak 60\% ke atas berprasangka orang Sunda "penakut ", "boros", "pemalas" dan "tertutup" atau inklusif hidupnya. Terhadap etnik Bugis $60 \%$ ke atas etnik Lampung, Sunda, Jawa, dan Batak berprasangka orang Bugis " angkuh", "kasar", dan "boros" hidupnya. Kemudian terhadap etnik Batak, $60 \%$ ke atas etnik Lampung, Jawa, Sunda, dan Bugis berprasangka bahwa orang Batak "angkuh", dan "kasar" prilakunya. Adapun terhadap etnik Lampung sendiri sebagai etnik 
pribumi, $60 \%$ ke atas etnik Sunda, Jawa, Bugis dan Batak berprasangka orang Lampung " angkuh", "kasar" dan "pemalas".

7. Aspek pengalaman seperti kedekatan pergaulan, aspek sosial budaya seperti agama, tingkat pendidikan, dan pekerjaan serta status sosial seseorang adalah faktor yang mewarnai persepsi dan prasangka antaretnik Sunda, Jawa, Lampung, Bugis, dan Batak di Bakauheni Lampung Selatan

\section{DAFTAR PUSTAKA}

Amrih. 2008. Ilmu Kearifan Jawa .Yogyakarta: Pinus.

Antonius Simanjuntak. 2009 Konflik Status dan Kekuasaan Orang Batak Toba.

Jakarata: Yayasan Obor , 2009

Aryanti, Nina Yuda, dkk. 2008. Potensi Wisata Budaya Lampung. Hasil Penelitian Hibah, Jakarta: Dikti

BPMD, 2009. Profil Desa Bakauheni, Kecamatan Penengahan Lamsel.

Creswell, John W. 1998. Qualitative Inquiry And Research Design Choosing Among Five Traditions. India. Sage Publication Inc. . 2002. Research Design. trj. Tim KIK UI. Jakarta : KIK Press.

Karomani. 2009. Komunikasi Antar Budaya, Studi tentang Persepsi, Prasangka dan Pengelolaan Kesan Verbal dan Nonverbal Antarelite Ulama, Jawara dan Umaro di Banten Selatan. Tangerang : Mata Baca Publishing.

Mulyana, Deddy., dan Rakhmat, Jalaluddin. ed. 2000. Komunikasi AntarBudaya Panduan Berkomunikasi dengan Orang-orang Berbeda Budaya. Bandung: Rosda Karya

Mulyana, Deddy. 2001. Metodologi Penelitian Kualitatif. Bandung: PT Remaja Rosda Karya.

Nazir. 1988. Metode Penelitian .Jakarta, Galia Indonesia.

Nurdin. 2009. Budaya Muakhi . Yogyakarta: Gama Media. 